\title{
An Empirical Study on Enhancing Product Quality and Customer Satisfaction Using Quality Assurance Approach in an Indian Manufacturing Industry
}

\author{
Ankesh Mittal \\ Department of Mechanical Engineering, \\ Sant Longowal Institute of Engineering \& Technology, Longowal, Punjab, India. \\ Corresponding author: ankeshmittal07@gmail.com

\section{Pardeep Gupta} \\ Department of Mechanical Engineering, \\ Sant Longowal Institute of Engineering \& Technology, Longowal, Punjab, India. \\ E-mail: pardeepmech24@gmail.com \\ (Received on September 17, 2020; Accepted on February 1, 2021)
}

\begin{abstract}
The aim of this paper is to investigate the utilization of quality assurance approach in improving the product quality and customer satisfaction while implementing total quality management (TQM) initiatives in leading tractors manufacturing industry situated in Mohali, Punjab, India and highlight the improvements that have taken place as a result of these initiatives. ABC Ltd. (name changed) started implementing TQM as a business management approach in 2007 and its implementation helped the organization to excel in quality, cost and delivery to gain flexibility, provide quality products of wide range and gain operational excellence. Initially, the focus of the industry was on traditional approach that is inspection and control but after TQM it got shifted to prevention of defects and quality assurance. Improvement in field quality, supplier quality and manufacturing quality were mainly focused under quality assurance approach in order to improve product quality and customer satisfaction. Implementation of TQM initiatives helped the industry to double the revenue, triple the profit in just three years and as a result the company got Deming Prize in 2012. The customer satisfaction index improved from 76 to 106, sales volume increased from 27000 to 67000 tractors and market share enhanced from 9.1 to 12.6 percent after TQM deployment within a period of five years. The empirical study presented in this paper is a novel study on augmenting the product quality and customer satisfaction may give insight to the TQM practitioners in promoting similar approaches in their organizations for enhancing customer satisfaction and product quality.
\end{abstract}

Keywords- Total quality management, Quality assurance, Customer satisfaction, Continuous improvement.

\section{Introduction}

In the present scenario of fiercely competitive market, customers are looking for high quality products and services. Now to remain competitive, the main goal of any organization is to ensure the satisfaction level of their customers because satisfied customers lead to higher profits. Improving customer satisfaction is now a prime mission that tends to build value for customers, anticipate and manage their expectations, and exhibit ability and responsibility to satisfy their needs. The most important value of any organization is its customers and it has become its responsibility to always keeps them happy and satisfied. It is very important to determine the customers' perception on quality for products and services provided by any organization so as to meet their requirements. Many organizations have started implementing some business improvement tools viz. TQM, TPM, Lean Six Sigma, TEI, JIT, etc. for attaining continuous improvement in their operations and products to delight their customers. TQM has become popular because of the numerous studies confirmed its influence on performance and excellence. 
International Journal of Mathematical, Engineering and Management Sciences

Vol. 6, No. 3, 878-893, 2021

https://doi.org/10.33889/IJMEMS.2021.6.3.052

TQM is modern management thinking and an expedition, not a destination. Different TQM principles contribute varied impact on the business performance parameters viz. quality, cost, productivity, delivery, customer satisfaction, etc.

The TQM implementation at ABC Ltd. was initiated in 2007 that helped the industry in excelling in terms of quality, cost and delivery. Further the industry gained flexibility and manufacturing excellence so as to provide quality products of wide range to the customers. The success story of TQM implementation at ABC Ltd. motivated to investigate the tools and techniques used in improving the product quality and customer satisfaction through TQM initiatives. The role of quality assurance approach for improving the product quality and customer satisfaction has been revealed through a case study. This study will be able to give insight to the quality management practitioners on using similar practices for improving the quality and customer satisfaction of their organizations.

\section{Literature Review}

Over the past few decades, TQM has been widely adopted by many companies worldwide as well a good number of Indian industries to improve their operational capabilities for gaining business excellence. TQM refers to management methods used to enhance quality and productivity in organizations with an ultimate aim for improving business performance. TQM is both a set of guiding principles and philosophy that represents the foundation meant for continuously improving organizations (Abbeh et al., 2019; Garg et al., 2013). TQM practices specifically designed to provide for their individual requirements (Mateos-Ronco and Hernández Mezquida, 2018). Soft factors include elements like supplier relationships, commitment and training. According to Metaxas and Koulouriotis, (2019) hard factors like tools and techniques necessary to control and improve processes and products. TQM is one of the most vital strategies for achieving customer satisfaction and higher profit (Anil and Satish, 2016; Garg et al., 2013; Shen and Tang, 2018). TQM gives a framework for executing important quality initiatives that can improve the productivity, quality and competitiveness of organizations (Saad and Khamkham, 2018; Yan et al., 2019). The success of a firm is highly dependent on treating the quality improvement as a never ending mission (Ishikawa, 1985).

Several studies (Haile and Raju, 2016; Kumar and Sharma, 2017; Kumar et al., 2018) claimed that TQM gives a set of critical success factors that focus on continuous improvement, customer satisfaction, employee empowerment and involvement, team work, process management, supplier management, top management commitment, education and training, benchmarking and using of tools and techniques. Mehra et al. (2001) suggested that every organization must change their focus in the direction of customer satisfaction as it enhances company's performance. On account of the competitive global market, customers can go for a variety of branding options. This necessitated the organizations to make sincere efforts to improve their products/services (Belobaba, 2009). The product image of the company has a significant impact on customer satisfaction (Anil and Satish, 2019; Pattanayak et al., 2017). The product quality (Mittal and Gupta, 2018) is also an important aspect which influences customer satisfaction levels and it is also observed that if customers are not satisfied they are more likely to switch over to alternate brands (Alfalah, 2017; García-Alcaraz et al., 2019; Nguyen and Nagase, 2020). In the field of Total Quality Management, little bit confusion across the worldwide with the philosophy of TQM and the effects of TQM implementation (Kumar et al., 2020). 
TQM is being adopted for raising the level of performance of Indian organization to world class level (Oliveira et al., 2019). Goldman, (2005) observed that many organizations adopted TQM to save millions of dollars. Mehra and Ranganathan, (2008) found that effectively implemented TQM initiatives surely impact on level of customer satisfaction. Terziovski and Samson, (1999) studied that with the help of TQM programs manufacturing industries are more likely to achieve successes in terms of customer satisfaction and business performance. TQM maintain the quality level in every sector by improving the performance of products, services and processes (Gupta and Mittal, 2020; Kumar et al., 2010; Sweis et al., 2019). To stay competitive in market organization must to explore innovative ideas to manage excellence in business (Laxmikumari et al., 2014). To eliminate the relationship risk between organization and customers, it was necessary to implement TQM (Tisca et al., 2015). Many manufacturing organization using quality circles a problem solving for cost saving and improvements in quality of product/service (Sharma, 2013; Silombela et al., 2018). The TQM initiatives Kaizen and total employee involvement (TEI) are important to impact on continuous improvement and customer satisfaction (Kumar, 2019; Shaharudin et al., 2008). The literature review reveals that TQM is a useful area of research to explore better opportunities for giving more benefits to industries. Most of the researches are on the TQM implementation in different types of industry, study on the success factors and barriers encountered and them inter relationships. There are studies of both success and failure as a result of implementation of TQM in industries within the country as well as abroad. Therefore, it has been found that there is a gap in understanding the TQM philosophy and its implementation procedure adopted by Indian Industries. Secondly, there is a need to motivate TQM practitioners and researchers through real life case studies on how to improve product quality and customer satisfaction through TQM initiatives.

\section{Research Objectives}

The aim of this paper is to examine how total quality management (TQM) implementation played a significant role in improving the product quality with an ultimate purpose to enhance customer satisfaction at ABC Ltd. The following are the objectives of the proposed research.

(i) Identification of highly contributing causes responsible for poor quality of tractors.

(ii) Identification of TQM approaches used for improving field quality, supplier quality and manufacturing quality.

(iii) Explore the benefits attained by the industry.

\section{Research Methodology}

A case study research methodology has been used in this research paper (Kumar et al., 2016; Khandelwal, 2020). To prepare this case study, required information and data has been collected by visiting the industry, having discussions with TQM team members and studied reports and result sheets available in the industry. A study has been prepared for investigating the impact of implementing TQM activities particularly in improving the product quality. The methodology used for purpose is presented by Figure 1. 


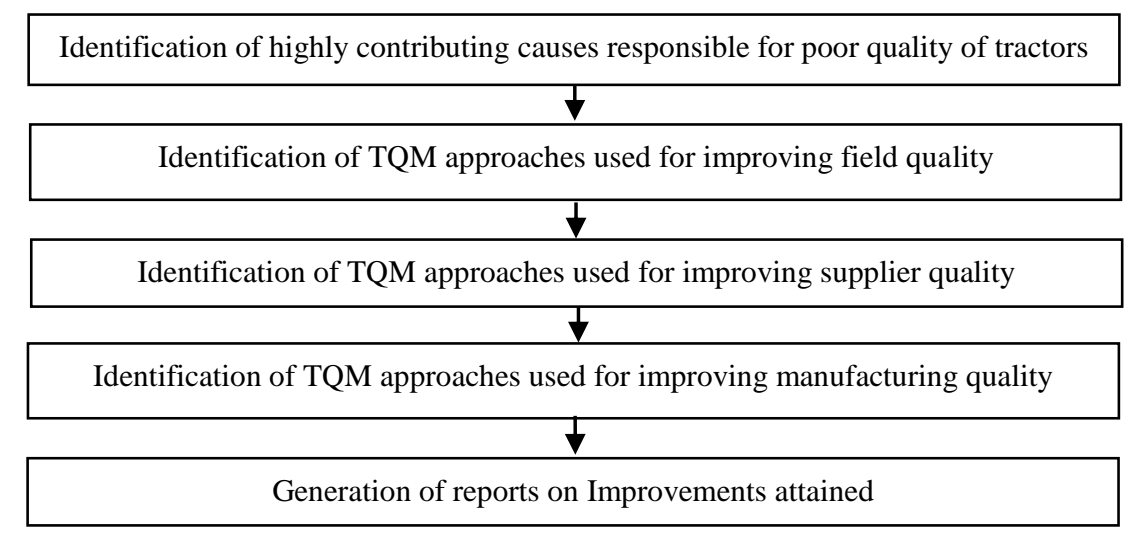

Figure 1. Methodology for implementing quality assurance approach.

\section{Improving Product Quality Using Quality Assurance Approach}

ABC Ltd. is one of the prime tractors manufacturing industry situated in Punjab, India and manufactures about 300 tractors per day. Presently, the tractors manufacturing industry under study was facing intense competition with the presence of eight major players in the market. The market position of ABC Ltd. on account of customer satisfaction weakened from second to fifth during 2000 to 2008 because of strong competition. Its market shares also reduced from $18.5 \%$ to 9.1\%, Customer Satisfaction Index (CSI) was 76 and 79 in 2008 and 2009 respectively. Thus the challenges before the industry were to gain first/second position on customer satisfaction level, improve market share and profitability. The company was also facing some quality related issues such as field quality, manufacturing quality, supplier quality and service quality. Therefore, to address these issues by the company a strategic approach was adopted by the company. Vision formulation was the first step of TQM implementation methodology. Based upon the consent of customers, suppliers and dealers, the vision of the company was formulated as "To be within top two brands in India". Different strategies and TQM activities were planned and executed for attaining the set vision. To enhance customer satisfaction and confidence in product quality, several initiatives such as improving quality of products and processes, and reduce variation and prevention of defects at design and development stages have been taken. This was achieved by integrating quality assurance and quality improvement activities with the establishment of Quality Management System for improving product quality and customer satisfaction.

Before implementation of TQM, the company was facing some quality related issues such as field failures, manufacturing quality and supplier quality. The field failure rejection rate was 2.34 Repairs per Hundred $(\mathrm{R} / \mathrm{H})$ during initial running of tractors in $0-100$ hours and $5.48 \mathrm{R} / \mathrm{H}$ in 0 250 hours. There was no mechanism for capturing and resolution of earlier hour field failures and in case of maintaining manufacturing quality, there used to be no focus on defect prevention and countermeasures were limited up to corrections only. The supplier quality was also not up to desired level and thus there was less number of suppliers who were allowed to supply the items direct on line (DOL), which was leading to high Goods Receipt (GR) \& Line rejections (LR).

Earlier the activities were organized by the industry as:

- Inspection of components received from suppliers.

- Inspection of In-house machined \& painted components. 
- Inspection of final product.

- Warranty claims settlement.

To counter these manufacturing quality issues, the company adopted the following quality initiatives under TQM:

- Improvement in Field Quality.

- Improvement in Supplier Quality.

- Improvement in Manufacturing Quality.

\subsection{Improvement in Field Quality}

Earlier the focus of the company was limited to warranty claims and no process was followed for capturing and resolution of earlier hour field failures. Early hour field failure was one of the main concerns of customer dissatisfaction. The field failure rejection rate was 2.34 Repairs per Hundred $(\mathrm{R} / \mathrm{H})$ during initial running of tractors in $0-100$ hours and $5.48 \mathrm{R} / \mathrm{H}$ in $0-250$ hours. To improve the early hour field failure of tractors, a Cross Functional Team (CFT) was formulated whose first priority was to identify the top contributing defects in order to reduce the field failures.

The following steps were carried out by CFT:

(i) Identifications of defects

(ii) Prioritization of defects in order to overcome the most contributing defects

(iii) Preparation of Quality Assurance (QA) matrix

(iv) $\quad 4 \mathrm{M}$ analysis and identification of root cause

(v) Solution finding through Kaizen

(vi) Implementation of Kaizen findings

(vii) Confirm results

(viii) Horizontal deployment.

The following two projects were taken out by the company to satisfy the customers' needs, which resulted in the improvement of field quality.

\subsubsection{Reduction in Transmission Noise}

A customer survey was carried out in 2011 to identify the main concerns of customers about the tractors performance problems. The survey revealed that transmission noise is one of the major issues. Field Visits were done by QA Team to confirm the concern of transmission noise. Relevant process study and data analysis was done and it was observed that a monotonous noise occurred when tractors were put in fourth gear. This noise used to start at $1400 \mathrm{rpm}$ and amplify further with increase in speed. Based on field visit findings, in-house testing of tractors was carried out and the same concerns were observed in twenty-eight tractors. Then it was decided to eliminate this problem from twenty-eight tractors to zero based on in-house observations.

In order to identify the probable causes, detailed analysis was done. Four probable causes were identified such as backlash between crown and tail pinion, preloading, top relief and run out of crown wheel. For the recognition of major root cause, a quality improvement tool such as Design of Experiment (DOE) was used. Out of four causes, the backlash between the crown and tail pinion was identified as the main root cause for high gear noise. 
The DOE findings further suggested that a backlash of $0.3 \mathrm{~mm}$ may give best results in reducing the transmission noise. As a countermeasure, the backlash range was increased from $0.15-0.25$ $\mathrm{mm}$ to $0.25-0.35 \mathrm{~mm}$. This correction resulted in resolving the problem of high transmission noise as evident from Figure 2.

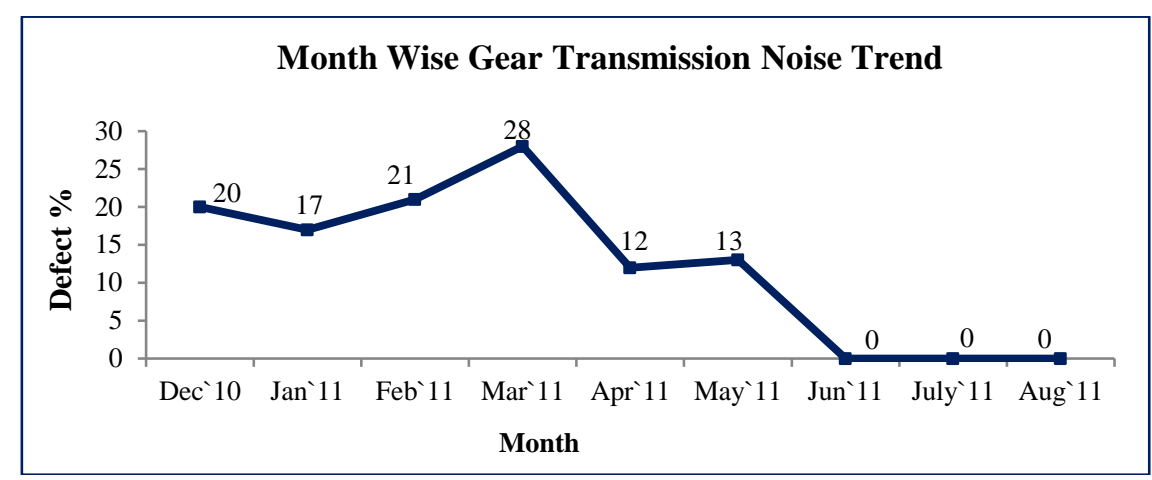

Figure 2. Gear transmission noise trend.

\subsubsection{Improvement in Angle Bracket Failure}

The second major cause for field failures was because of the angle bracket failure occurring in early 0-250 hours. Quality Control Story as an improvement tool was used to reduce angle bracket failure from $0.08 \%$ to zero by October 2011. The project was initiated in April, 2011 and completed in November, 2011. Good and bad tractor samples were tested under the design load conditions. The bad tractors used to qualify the pass criteria but failed under warranty period when used in fields. The field visits were carried out and during this, it was found that the failed tractors used to bear the transportation load of 14-16 tons against the design limit of 12 tons. Because of this excessive loading condition, a crack used to be generated in the angle brackets that remained responsible for its failure. To further verify failures due to heavy loading conditions, simulation was done in the lab with an increased load of 18 tons as against design load of 12 tons. It was found that due to the less structural strength of angle bracket, sample tractor failed the pass criteria of one Lac cycles in 0-250 hours. Countermeasures with two design modifications were implemented after the validation in simulation lab.

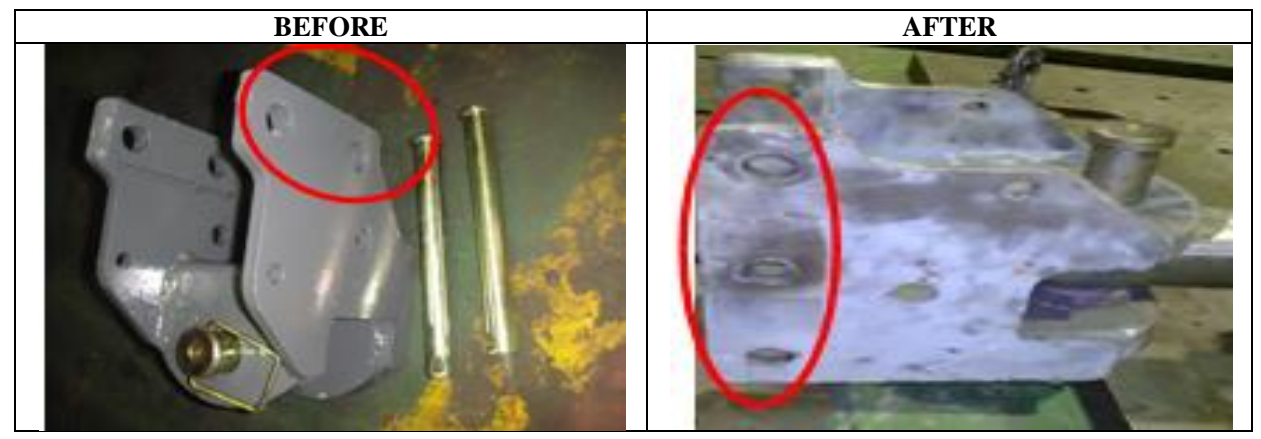

Figure 3. Angle bracket before and after application of solution. 
The QA team proposed design modifications and suggested i) repositioning of mounting holes of trailer hook to reduce stress level at failed zone of angle bracket and ii) to increase the number of mounting holes from two to three in the angle bracket as shown in above Figure 3. After this corrective action the angle bracket failures got completely eliminated as per the failure trend presented in Figure 4.

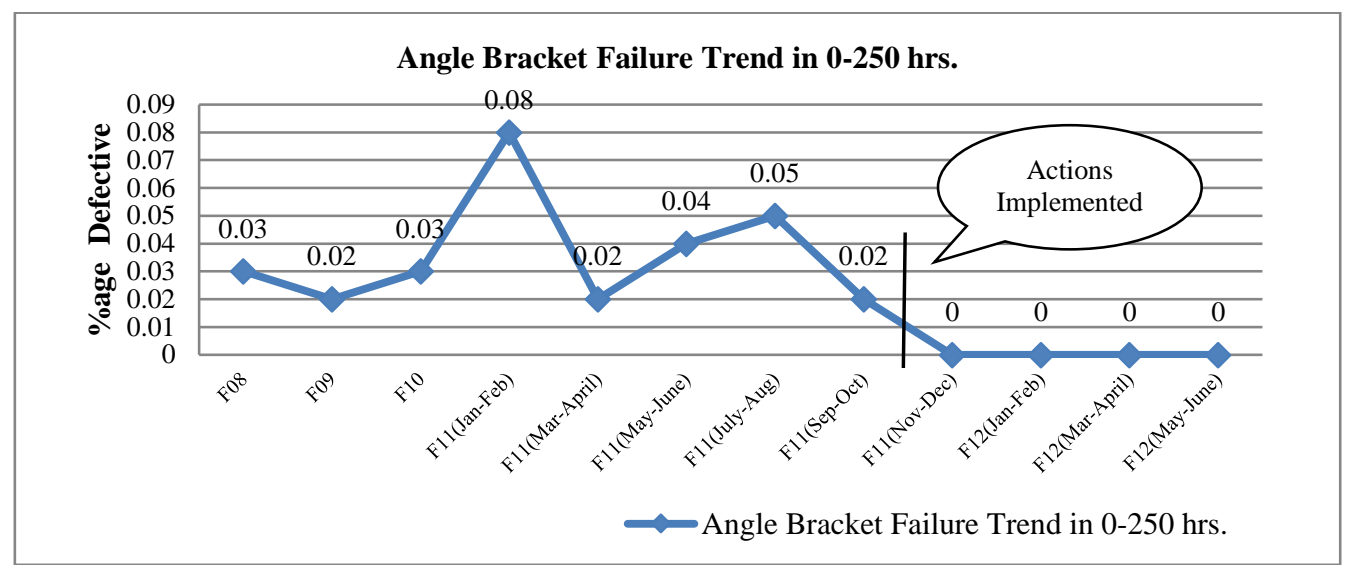

Figure 4. Reduction in angle bracket failure.

To avoid such failures in all the models of tractors these preventive actions are standardized.

- Repositioning of mounting holes of trailer hook to reduce stress level at failed zone of angle bracket.

- Number of mounting holes increased to 3.

\subsection{Improvement in Supplier Quality}

The poor supplier quality was one of the issues before implementation of TQM. The main reason for this was low support to suppliers of the company on quality improvement issues. Goods receipt (GR) lot rejection pertaining to casting and forging was $11.03 \%$, GR lot rejection from others was $7.52 \%$. Line rejection (LR) was 390 PPM and only a few suppliers used to supply the items Direct on Line (DOL) in assembly section. So there was a need to improve supplier quality to address higher rejection rate and to upgrade the suppliers so that they can provide their products Direct on Line (DOL). To improve quality of suppliers, following activities were carried out.

\subsubsection{Quality Assured Components-Direct on Line (DOL)}

Components were identified for the supply on DOL based upon last six months GR and LR rejection trends. The manufacturing processes and QA systems were established at supplier end which were validated through audits. Components were declared as DOL if supplier demonstrates adherence to the system and GR rejection was zero and LR was less than 100 PPM for consecutive two months. After declaring DOL, periodic audits were conducted at the supplier end for the sustenance of system. Direct on line component goes directly to assembly line skipping receipt inspection displaying confidence in the established system. With this initiative of DOL declaration approach total 1495 components declared as DOL. The DOL process used by ABC as presented in Figure 5. 


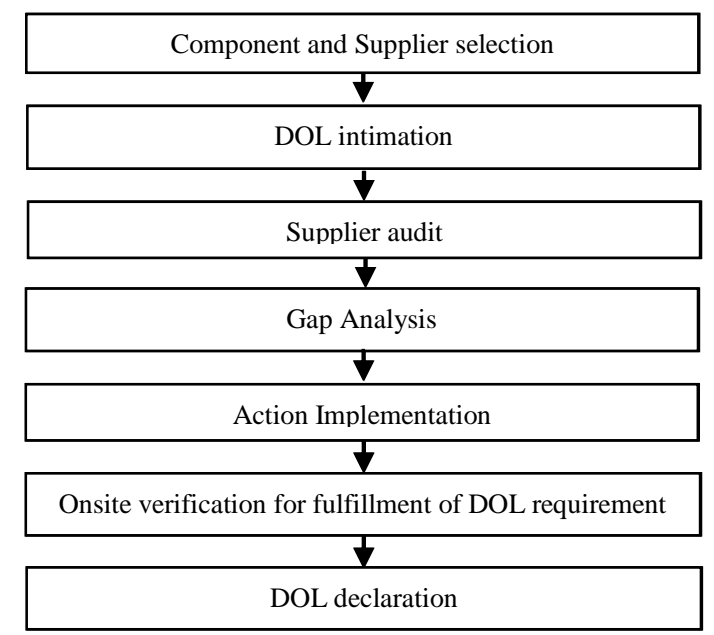

Figure 5. Direct on line declaration process.

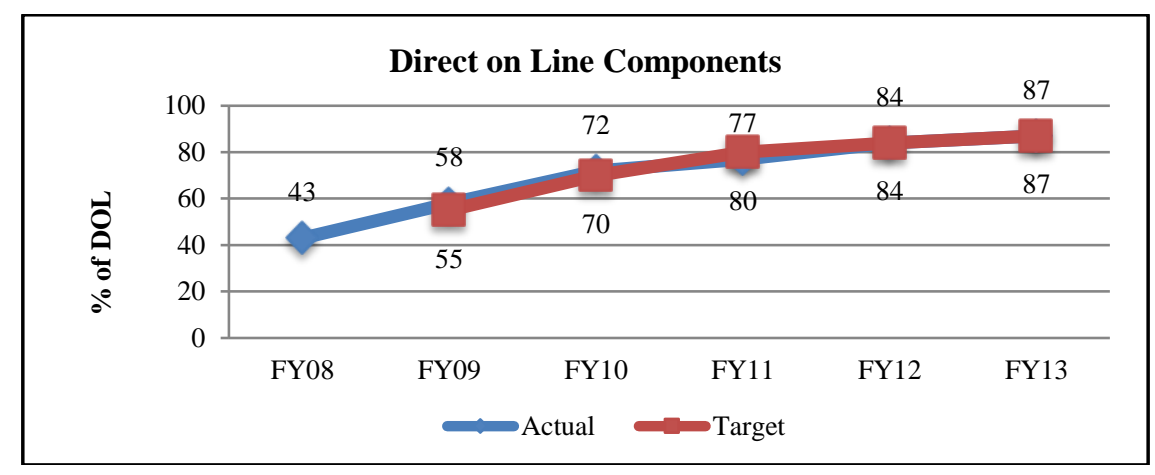

Figure 6. Trend of components DOL.

With the implementation of the supplier management activities, GR rejections were reduced to zero; overall LR was less than 100 PPM for two consecutive months and the supply of components DOL different suppliers increased to $84 \%$ as shown in Figure 6.

\subsubsection{Reduction of Goods Receipt (GR) Lot Rejection}

In order to reduce GR lot rejection, top contributing suppliers and components were identified through rejection data analysis. Manufacturing process of contributing components was assessed at supplier end. Processes were reviewed against the reason for non-conformities to the specifications. Gaps in the process or checking methods were identified and actions were implemented. Problems were systematically resolved through seven step problem solving and Kaizen by a Cross Functional Team (CFT) comprising of sourcing and QA representatives. At the same time, critical to quality (CTQ) parameters were identified for $100 \%$ checking. Pre dispatch inspection check points were also revised to incorporate parameters responsible for cause of variation. Presence of welding crack in clutch actuator shaft was among the top GR lot rejection contributors due to wrong welding operation. It was contributing $12.5 \%$ in forging lot rejection. A CFT comprising of quality assurance and sourcing visited supplier to study the process from raw 
material receipt stage to welding stage. With the help of why-why analysis the two causes were identified as more clearance in child part and concave welding pattern. To eliminate these causes the two countermeasures were taken as (refer Figure 7).

- Reaming process is introduced in lever after piercing process to control the hole size.

- MIG welding set up is established instead of Arc welding for producing Convex welding pattern.

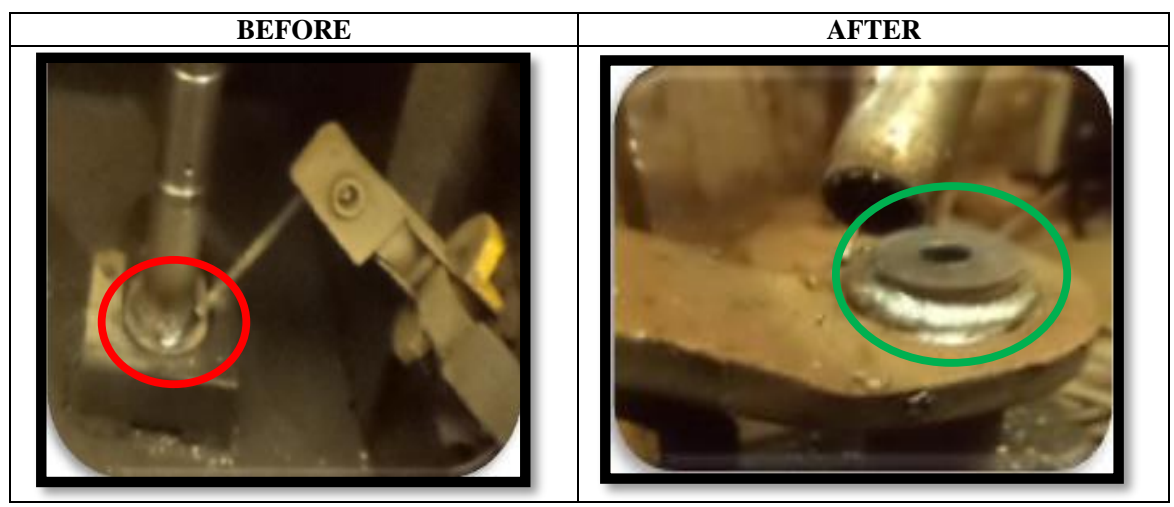

Figure 7. Before (Arc) and after (MIG) welding pattern.

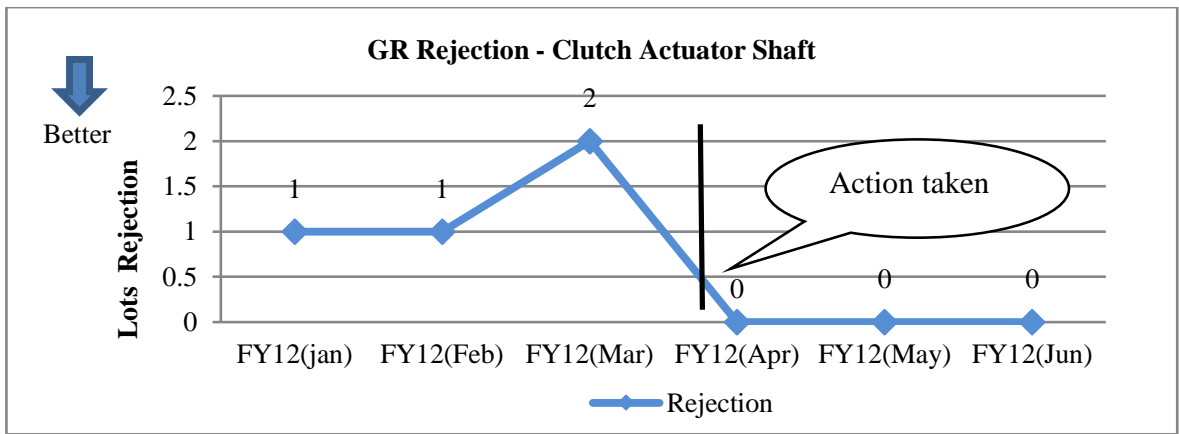

Figure 8. Reduction of GR lot rejection.

After taking this countermeasure, elimination of the problem as shown in Figure 8 took place. Further with rejection data analysis, total 265 improvements were carried out in 2013 which improved the GR\% by $30 \%$.

\subsubsection{Reduction in Line Rejection (LR)}

Line rejected components supplied by different suppliers were analyzed. Parameters which were held responsible for the reason of line rejection on assembly line were identified. To avoid the recurrence of line rejections, corrective actions were ensured at supplier end. Additionally, same parameters were added as inspection check point at receipt stage. An example of improvement carried out to reduce line rejection, gear box housing was among the top contributors in LR in the month of October 2011. Less idle gear (IG) bore wall thickness in gear box casting was the one major reason for rejection. A cross functional team comprising of quality assurance and sourcing 
International Journal of Mathematical, Engineering and Management Sciences

Vol. 6, No. 3, 878-893, 2021

https://doi.org/10.33889/IJMEMS.2021.6.3.052

visited a supplier to evaluate manufacturing processes of idle gear. After the detailed analysis, it was observed the core shift leads to less wall thickness. Further analysis evaluated that inadequate guiding in loose core and lesser diameter of loose core are also contributing causes. To eliminate these causes the two actions were taken as:

- Loose core making process optimized by introducing taper type guide.

- Diameter of loose core corrected and monthly check added.

After taking these corrective actions elimination of the problem took place as shown in Figure 9. Standardization was done with SOP revision, and finally rejection of LR got reduced from 390 PPM (2008) to 140 PPM (2012).

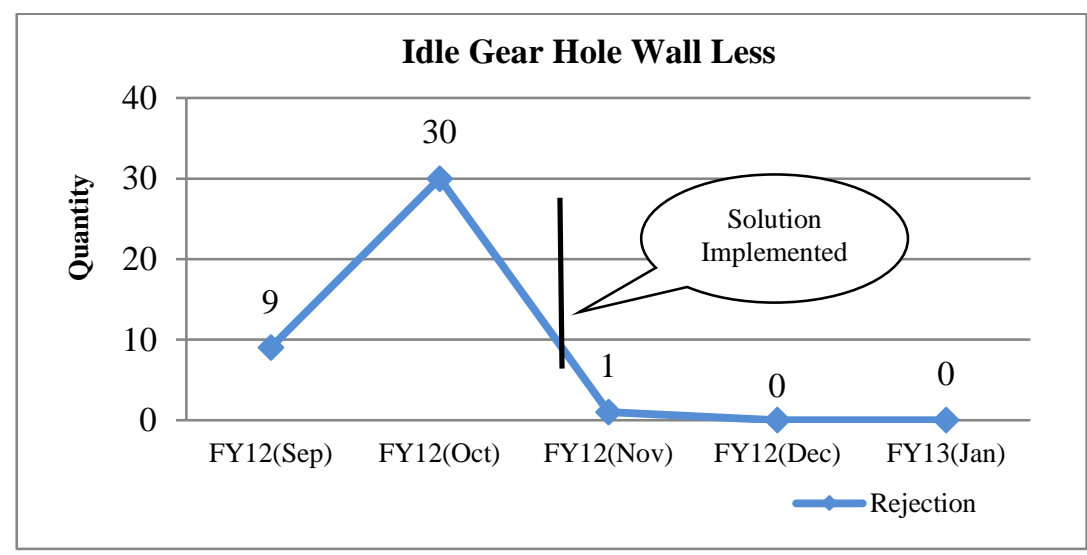

Figure 9. Reduction of LR rejection.

\subsection{Improvement in Manufacturing Quality}

Before the implementation of TQM, the focus of the company was merely on inspection but not on prevention of defects. There was lack of awareness related to the prevention of the defects and countermeasures were limited to corrections only. To overcome the issues related to manufacturing quality following initiatives were taken by company, so that defects free tractor can be supplied to the customers.

- Process Audit (Manufacturing Process).

- Product Audit (Evaluation of tractor from customer point of view).

\subsubsection{Process Audit}

Standard Operating Procedures (SOPs) were developed by the company which came in practice to produce the quality products. The SOPs were deployed in machine shop, paint shop and assembly shop. Quarterly process audits were initiated to find drawbacks in the current SOPs. The improvement in SOPs was carried out to improve the performance of manufacturing processes. Audits were carried out by the skilled quality assurance employees tracked by sharing of the feedback with the shop supervisors. Based upon the audit feedback, the shop supervisors used to take remedial and protective actions after modifying the SOPs. With all these efforts, 140 SOPs were revised, the SOP adequacy of machine shop increased from $74 \%$ to $93.2 \%$ and finally the Direct Pass Ration (DPR) increased from $81 \%$ to $98.2 \%$ in assembly shop. 
To enhance the DPR of the tractors manufactured by the industry, some of the kaizen projects were carried out with team approach. To evaluate the value of Direct Pass Ratio (DPR), its expression is given by the following equation.

$$
\text { Direct Pass Ratio }(\text { DPR })=\frac{(\text { Total Tractors produced }- \text { Total tractors defective })}{\text { Total Tractors produced }} X 100 .
$$

The three major Kaizens were also performed in 2011 and 2012 to raise DPR, and their results are highlighted as:

\section{Kaizen-1}

Problem: High tractor rework due to improper fitting of data plate

Root cause: Large drill length

Kaizen/Action Proposed: To reduce the length of the drill from $15 \mathrm{~mm}$ to $10 \mathrm{~mm}$.

Results: As a result of implementing the solution of this Kaizen project, the number tractors rework due to improper fitting of data plate come down to zero as shown in Figure 10.

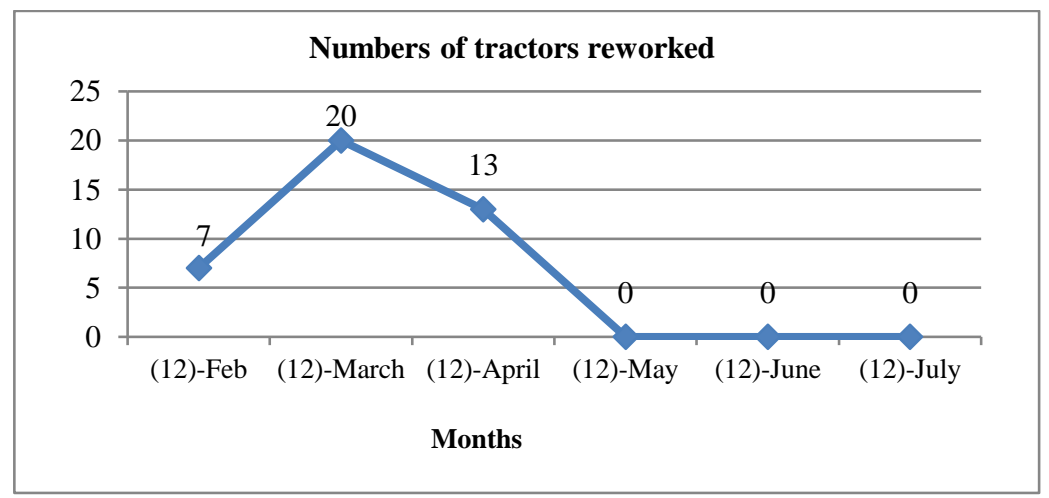

Figure 10. Reduction of tractor rework due to improper fitting of data plate.

\section{Kaizen-2}

Problem: Leakage from break drum.

Root cause: Faulty method of locating gasket without support between break drum housing and cover pate.

Kaizen/Action Proposed: To use studs on break drum housing for providing support to gasket and for proper location between break drum and cover plate.

Results: As a result of implementing the solution of this Kaizen project, the number tractors rework due to break drum leakage reduced to zero as shown in Figure 11. 
International Journal of Mathematical, Engineering and Management Sciences

Vol. 6, No. 3, 878-893, 2021

https://doi.org/10.33889/IJMEMS.2021.6.3.052

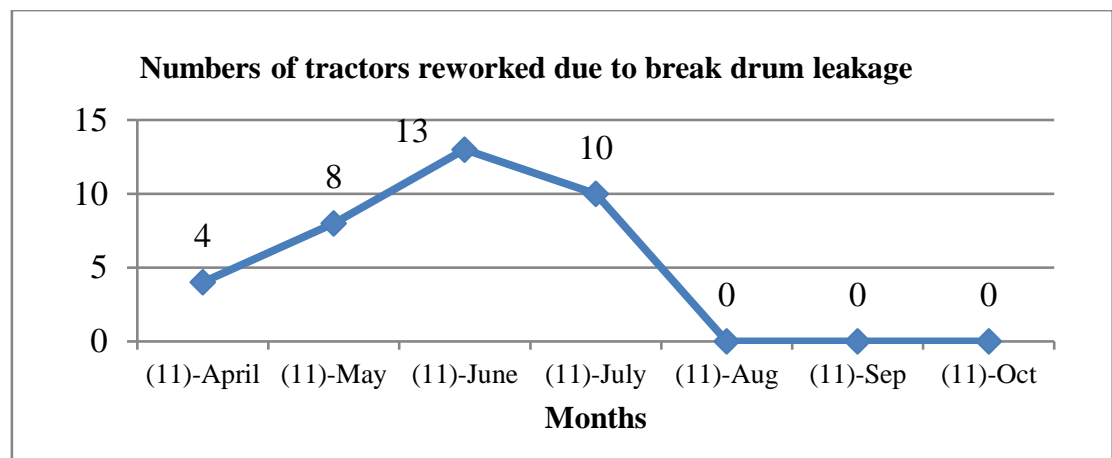

Figure 11. Reduction of tractor rework due to break drum leakage.

\section{Kaizen-3}

Problem: Leakage of diesel from water separator.

Root cause: Tube not fitted properly because of oil filters and water separator banjo is not accessible.

Kaizen/Action Proposed: To use a proper tool and stand as proposed by Kaizen Team for the tightening of banjo bolt of water separator pipe.

Results: As a result of implementing the solution of this Kaizen project, the number tractors rework due to tube not fitted properly became zero as shown in Figure 12.

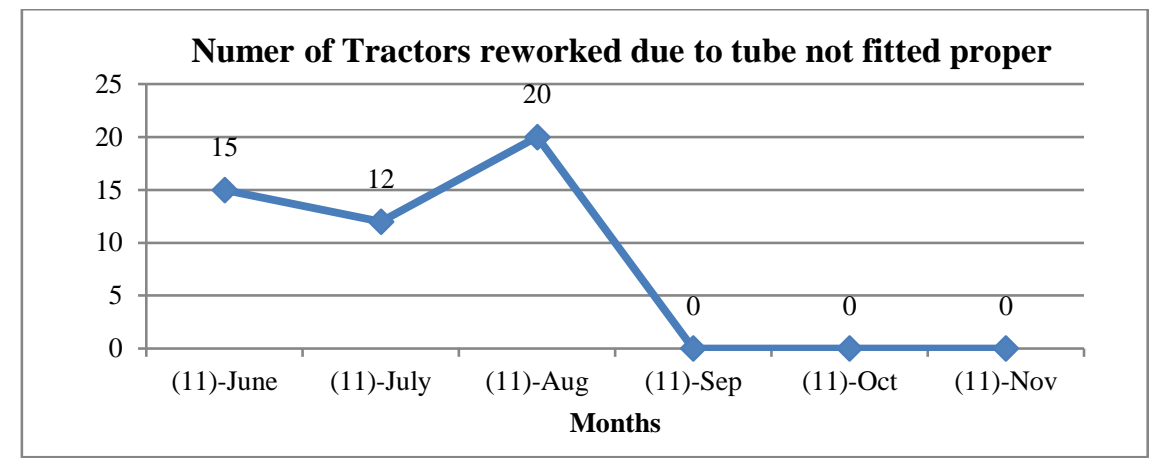

Figure 12. Reduction of tractor rework due to tube not fitted proper.

\subsubsection{Product Audit}

Product Audit was started in 2008, to evaluate and improve final product quality from customer's point of view. Evaluation score used to be awarded based on performance testing and aesthetic evaluation. Performance testing includes engine performance testing, extended roller testing, road testing with 2.5-ton trolley for six hours, hydraulic testing, checking of engine and transmission noise. Aesthetic evaluation includes inspection of sheet metal defects such as weld marks, scratches, pin holes, sheet burning etc.; paint defects such as dust, paint run down, less paint, paint over spray, color; and handling defects such as dents, paint chip off, paint scratches is carried out in special illuminated area. 
International Journal of Mathematical, Engineering and Management Sciences

Vol. 6, No. 3, 878-893, 2021

https://doi.org/10.33889/IJMEMS.2021.6.3.052

\section{Results and Discussion}

The implementation of quality assurance initiatives at ABC Ltd. remained highly successful in improving the field quality, supplier quality and manufacturing quality of its products. The target of the company was to reduce the field failures nearly to zero and the same was gained by the company with in a period of four years. Tailor hook bend broken, sensor tube breakage and leakage from control valve responsible for field failures reduced to zero with an average reduction by $32 \%$. Machine shop rejection reduced by $82 \%$. The percentage suppliers to supply items direct on line improved from $43 \%$ to $84.02 \%$. The supplier quality improvement initiatives helped in reducing Goods Rejection (GR) of castings and forgings from 11.03 to 2.49 and Line Rejection (LR) rejections reduced from 390 PPM to 140 PPM. Process Audit performed in assembly line helped in improving DPR to $90 \%$. Predominantly, as a result of countermeasures taken by quality assurance department, market share enhanced from 9.1 to 12.6 percent and there is exceptional enhancement in CSI score from 76 in 2008 to 119 in 2017. The CSI score of ABC Ltd. remained highest in tractors industry in India since 2011 onwards and it is enjoying its top position till date. The work under study is within limited scope because of availability of the restricted data from the concerned industry.

\section{Managerial, Societal and Theoretical Implications}

The TQM deployment at ABC Ltd. facilitated in achieving excellence in manufacturing and business results as well as accomplished its short term business plan i.e. 'To achieve double the revenue and three times profit in three years. The commencement of different TQM approaches has helped the company to continuously remain customer focused. The highlights and findings of this paper may give insight to TQM managers to promote similar TQM approaches for improving customer satisfaction, product quality, cost, etc. Under the TQM, the industry also carried out some important activities under corporate social responsibility for the betterment of the society.

\section{Conclusions}

The implementation TQM initiatives performed through Quality Assurance Section at ABC Ltd. remained highly successful with a purpose to improve the field quality, supplier quality and manufacturing quality. This was achieved by integrating quality assurance and quality improvement activities which remained helpful in improving the product quality and customer satisfaction. The TQM journey at ABC Ltd. remained predominantly successful and the industry got Deming Award in 2012 within a time period of four years. The vision of the company was to be within top two brands in India and the same was achieved from 2011 onwards and it is enjoying its top position till date. An empirical investigation of exploring the key benefits achieved will be of immense help to the TQM practitioners and researchers for promoting the implementation of innovative TQM approaches in Indian industries. Thus it can be concluded that the implementation of QA initiatives as a part of TQM played a prominent role in improving the overall product quality that contributed in enhancing the customer satisfaction. The intangible benefits gained by the industry were: Improved customer focus, improved problem solving capability, and improved cross functional team work. The limitation of this study was that the industry only allowed to have limited access in sharing the data and was reluctant in providing the detailed data and other relevant information for carrying out more meaningful research. The mediating relationships between TQM principles and various performance measures can also be analyzed in future studies. 
International Journal of Mathematical, Engineering and Management Sciences

Vol. 6, No. 3, 878-893, 2021

https://doi.org/10.33889/IJMEMS.2021.6.3.052

\section{Conflict of Interest}

The authors declare that they have no conflict of interest to declare for this publication.

\section{Acknowledgements}

The authors express their gratitude to the management and TQM team members of ABC Ltd. for extending support in preparing the case study and providing the required information and data.

\section{References}

Abbeh, O., Ngige, C.D., \& Azuka, O.M. (2019). Total quality management and organisational performance: an exploration of issues. Advanced Journal of Management, Accounting and Finance, 4(6), 48-68.

Alfalah, T.F. (2017). Total quality management tools: are they necessary for improving service quality and customer satisfaction? International Review of Management and Marketing, 7(3) 121-125.

Anil, A.P., \& Satish, K.P. (2016). Investigating the relationship between TQM practices and firm's performance: a conceptual framework for indian organizations. Procedia Technology, 24, 554-561.

Anil, A.P. \& Satish, K.P. (2019). Enhancing customer satisfaction through total quality management practices-an empirical examination. Total Quality Management \& Business Excellence, 30(13-14), 1528-1548.

Belobaba, P. (2009). Fundamentals of pricing and revenue management. In: Belobaba, P., Odoni, A., \& Barnhart, C. (eds) The Global Airline Industry. John wiley \& sons, pp. 73-111.

García-Alcaraz, J.L., Montalvo, F.J.F., Sánchez-Ramírez, C., Avelar-Sosa, L., Saucedo, J.A.M., \& AlorHernández, G. (2019). Importance of organizational structure for TQM success and customer satisfaction. Wireless Networks, 1-14.

Garg, K.K., Mishra, P., \& Sehrawat, S. (2013). The quest for excellence: a case study of TQM practice in tata steel. International Journal of Management, 3(1), 24-29.

Goldman, H.H. (2005). The origins and development of quality initiatives in American business. The TQM Magazine, 17(3), 217-225. https://doi.org/10.1108/09544780510594180

Gupta, P., \& Mittal, A. (2020). Identifying the most influencing success factors of TQM implementation in manufacturing industries using analytical hierarchy process. In 2020 International Conference on Industrial Engineering and Operations Management (pp. 541-552). IEOM. Dubai, UAE.

Haile, Y., \& Raju, S. (2016). The extent of TQM practices in Ethiopian manufacturing firms: an empirical evaluation. International Journal of Applied Research, 2(5), 238-244.

Ishikawa, K. (1985). What is total quality control? the Japanese way (business management). Prentice Hall Trade.

Khandelwal, A. (2020). Case studies of sustainable road transport practices in different industry sectors in India. International Journal of Mathematical, Engineering and Management Sciences, 5(6), 10911107.

Kumar, J., Kataria, K.K., \& Luthra, S. (2020). Quality circle: a methodology to enhance the plant capacity through why-why analysis. International Journal of Mathematical, Engineering and Management Sciences, 5(3), 463-472.

Kumar, R. (2019). Kaizen a tool for continuous quality improvement in Indian manufacturing organization. International Journal of Mathematical, Engineering and Management Sciences, 4(2), 452-459. 
International Journal of Mathematical, Engineering and Management Sciences

Vol. 6, No. 3, 878-893, 2021

https://doi.org/10.33889/IJMEMS.2021.6.3.052

Kumar, R., Garg, D., \& Garg, T.K. (2010). TQM success factors in North Indian manufacturing and service industries. The TQM Journal, 23(1), 36-46.

Kumar, V., \& Sharma, R.R.K. (2017). Exploring critical success factors for TQM implementation using interpretive structural modelling approach: extract from case studies. International Journal of Productivity and Quality Management, 21(2), 203-228.

Kumar, V., Sharma, R.R.K., Verma, P., Lai, K.K., \& Chang, Y.H. (2018). Mapping the TQM implementation: an empirical investigation of the cultural dimensions with different strategic orientation in Indian firms. Benchmarking: An International Journal, 25(8), 3081-3116.

Kumar, V., Verma, P., Onkar, S.P.S., \& Katiyar, J. (2016, March). Facility and process layout analysis of an SME using simulation: a case study of a manufacturing company. In 2016 International Conference on Industrial Engineering and Operations Management (pp. 1294-1304). IEOM. Kuala Lumpur, Malasiya.

Laxmikumari, Kumar, Y.V., \& Ramana, V.V. (2014). Total quality management (TQM) a quality and performance enhancer. International Journal of Engineering and Science, 4(8), 91-94.

Mateos-Ronco, A., \& Hernández Mezquida, J.M. (2018) Developing a performance management model for the implementation of TQM practices in public education centres. Total Quality Management \& Business Excellence, 29(5-6), 546-579.

Mehra, S., \& Ranganathan, S. (2008). Implementing total quality management with a focus on enhancing customer satisfaction. International Journal of Quality \& Reliability Management, 25(9), 913-927.

Mehra, S., Hoffman, J.M., \& Sirias, D. (2001). TQM as a management strategy for the next millennia. International Journal of Operations \& Production Management, 21(5/6), 855-876.

Metaxas, I.N., \& Koulouriotis, D. E. (2019). Business excellence measurement: a literature analysis (19902016). Total Quality Management \& Business Excellence, 30(11-12), 1189-1218.

Mittal, A., \& Gupta, P. (2018, July). Quality Improvement of Intermediate Shaft used in Steering Column through TQM: A Case Study. In $2^{\text {nd }}$ European Conference on Industrial Engineering and Operations Management (pp. 963-971). IEOM. Paris, France.

Nguyen, T.L.H., \& Nagase, K. (2020). Total quality management: a mediating factor in the relationship between customer expectations and satisfaction. International Journal of Management and Marketing Research, 13(1), 1-13.

Oliveira, G.S., Corrêa, J.E., Balestrassi, P.P., Martins, R.A., \& Turrioni, J.B. (2019). Investigation of TQM implementation: empirical study in Brazilian ISO 9001-registered SMEs. Total Quality Management \& Business Excellence, 30(5-6), 641-659.

Pattanayak, D., Koilakuntla, M., \& Punyatoya, P. (2017). Investigating the influence of TQM, service quality and market orientation on customer satisfaction and loyalty in the Indian banking sector. International Journal of Quality \& Reliability Management, 34(3), 362-377

Saad, S.M., \& Khamkham, M.A. (2018). Development of an integrated quality management conceptual framework for manufacturing organisations. Procedia Manufacturing, 17, 587-594.

Shaharudin, M.R., Hassam, S.F., Akbar, J., Rashid, N.R.N.A., \& Noor, N.F.N.M. (2008). Determinants of ISO 9001 quality management system effectiveness amongst electrical and electronics manufacturing firms in Malaysia. International Journal for Quality Research, 12(3), 655-676.

Sharma, C. (2013). Quality circle: an evolutionary tool for libraries. International Journal of Advanced Research in Management and Social Sciences, 2(5), 154-159.

Shen, J., \& Tang, C. (2018). How does training improve customer service quality? The roles of transfer of training and job satisfaction. European Management Journal, 36(6), 708-716. 
International Journal of Mathematical, Engineering and Management Sciences

Vol. 6, No. 3, 878-893, 2021

https://doi.org/10.33889/IJMEMS.2021.6.3.052

Silombela, T., Mutingi, M., \& Chakraborty, A. (2018). Impact of quality management tools and techniques: case of Namibian municipal water distributors. Journal of Quality in Maintenance Engineering, 24(1), $2-21$.

Sweis, R., Obeidat, B. \& Kanaan, R.K. (2019). Reviewing the literature on total quality management and organizational performance. Journal of Business \& Management (COES \&RJ-JBM), 7(3), 192-215.

Terziovski, M., \& Samson, D. (1999). The link between total quality management practice and organisational performance. International Journal of Quality \& Reliability Management, 16(3), 226237.

Tisca, I.A., Dumitrescu, C.D., Cornu, G., \& Istrat, N. (2015). Management services in hospitality industry. Managerial Challenges of the Contemporary Society, Proceedings, 8(2), 175-177.

Yan, J., Zhang, K., Zhu, W., \& Fan, Y. (2019). An empirical framework for soft CSFs of TQM in Chinese manufacturing companies. The TQM Journal, 31(3), 377-399. 